\title{
PELATIHAN DIGITALISASI LITERASI KEUANGAN PADA PERSATUAN PEDAGANG BUKU, JASA PENGETIKAN, DAN GRAFIR INDONESIA (PEPEBUTINDO)
}

\section{FINANCIAL LITERACY DIGITALIZATION TRAINING AT THE INDONESIAN ASSOCIATION OF BOOK TRADERS, TYPING AND GRAFIR SERVICES (PEPEBUTINDO)}

\author{
Erwin Yulianto' \& Awan Setiawan² \\ Universitas Langlangbuana \\ eyulianto@unla.ac.id \\ 2Universitas Langlangbuana \\ awans2425@gmail.com
}

\begin{abstract}
ABSTRAK
Tingkat pengetahuan Literasi Keuangan pada Pelaku Usaha Mikro, Kecil, dan Menengah Kota Bandung pada umumnya dan Persatuan Pedagang Buku, Jasa Pengetikan dan Grafir Indonesia (Pepebutindo) yang menjadi mitra pengabdian kepada masyarakat masih tergolong rendah. Pihak akademisi terus mengedukasi para pelaku usaha yang bergerak di sektor UMKM. Respon positif dari pengurus dan anggota Pepebutindo pada wawancara mengenai Literasi Keuangan menunjukkan bahwa mereka siap bekerjasama dalam upaya penerapan digital mindset dan pengetahuan Literasi Keuangan. Kegiatan pengabdian menyelenggarakan tiga jenis kegiatan, yaitu penyusunan Petunjuk Teknis Digitalisasi Literasi Keuangan dan Workshop Digitalisasi Literasi Keuangan mengunakan aplikasi SI APIK. Dengan terlaksananya acara tersebut dan serah terima sebanyak lima puluh juknis SI APIK, berdampak terhadap peningkatan pengetahuan dari para pedagang yang berada di bawah naungan Pepebutindo terkait Literasi Keuangan dan Digital Mindset.
\end{abstract}

Kata Kunci $\quad$ : Digital Mindset; Literasi Keuangan; Pepebutindo; SI APIK

\begin{abstract}
The level of knowledge of Financial Literacy in Micro, Small and Medium Enterprises of Bandung in general and the Association of Book Traders, Typing and Engraving Services of Indonesia (Pepebutindo) which are partners in community service are still low. Academics continue to educate business actors engaged in the UMKM sector. The positive response from the management and Pepebutindo members in interviews about Financial Literacy shows that they are ready to work together in efforts to implement a digital mindset and knowledge of Financial Literacy. The community service activity held three types of activities, namely the preparation of Technical Guidelines for the Digitalization of Financial Literacy and a Workshop on Digitalization of Financial Literacy using the SI APIK application. With the implementation of the event and the handover of fifty SI APIK technical guidelines, it had an impact on increasing knowledge of traders under Pepebutindo regarding Financial Literacy and Digital Mindset.
\end{abstract}

Keywords $\quad$ : Digital Mindset; Financial Literacy; Pepebutindo; SI APIK 


\section{A. PENDAHULUAN}

Sektor Usaha Mikro, Kecil, dan Menengah (UMKM) memberikan kontribusi yang signifikan dalam perekonomian Indonesia. Kontribusi sektor UMKM terhadap produk domestik bruto meningkat dari $57,84 \%$ menjadi $61 \%$ dalam lima tahun terakhir, terdiri dari usaha mikro $30,3 \%$, usaha kecil $12,8 \%$, dan usaha menengah $14,5 \%$. (UKM, 2017). Serapan tenaga kerja pada sektor ini juga meningkat, dari $96,99 \%$ menjadi 97,22 \% pada periode yang sama. Pembangunan dan perkembangan perekonomian negara Indonesia sangat bergantung pada UMKM, dikarenakan kemampuannya untuk menyerap banyak tenaga kerja sehingga berdampak pada berkurangnya jumlah pengangguran dan dapat meningkatkan pendapatan per kapita. (Sunardi, Nardi; Lesmana, Rosa; Kartono; Rudy; Hasbiyah, 2020)

Pada krisis global tahun 2008 lalu, sektor UMKM terbukti menjadi tulang punggung perekonomian Indonesia. Hal ini disebabkan sebagian besar UMKM di Indonesia adalah usaha mikro di sektor informal yang pada umumnya menggunakan bahan baku lokal dengan pasar lokal, sehingga tidak terpengaruh secara langsung oleh krisis global. (Sudaryanto, 2002). Peran signifikan sektor UMKM mendorong pemerintah untuk memberi perhatian besar pada sektor ini, terutama dengan mencanangkan program-program yang diharapkan mampu mendorong berkembangnya sektor UMKM.

Peran signifikan sektor UMKM mendorong pemerintah untuk memberi perhatian besar pada sektor ini, terutama dengan mencanangkan program-program yang diharapkan mampu mendorong berkembangnya sektor UMKM. Pemerintah mempunyai program Kredit Usaha Rakyat (KUR) untuk mendorong penyaluran kredit UMKM yang dijamin tanpa mempersyaratkan agunan tambahan dengan tingkat bunga disubsidi sebesar 7 s.d. $12 \%$ per tahun.

Pemerintah melalui LPEI memberikan kredit ekspor bagi UMKM dengan persyaratan minimal 50 tenaga kerja. Di tingkat daerah, Pemerintah Kota Bandung secara khusus meluncurkan program Kredit Melati untuk melawan rentenir yang menyasar para pelaku UMKM Kota Bandung. Nilai pinjaman ini mencapai Rp 500 ribu-30 juta/tahun. Selanjutnya dari perbankan juga dikenal dengan program Kredit Mesra yaitu pinjaman tanpa bunga dan agunan, yang bisa diperoleh di masjid, gereja, pura, wihara hingga kelenteng sebagai upaya untuk meningkatkan ekonomi umat. (Bandung, 2016).

Perhatian Pemkot Bandung merupakan angin segar bagi perkembangan UMKM, apalagi Kota Bandung merupakan salah satu kota dengan jumlah UMKM terbesar bila dibandingkan dengan kota-kota lain di Indonesia. Namun demikian, sektor ini juga menghadapi banyak masalah, antara lain keterbatasan modal kerja, sumber daya manusia yang rendah, dan kurang cakapnya penguasaan ilmu pengetahuan. (Sudaryanto, 2002).

Salah satu permasalahan yang umum diketahui adalah kurangnya pendidikan serta rendahnya literasi dan inklusi keuangan para pelaku UMKM. Hal ini terbukti melalui pengukuran tingkat literasi keuangan UMKM di Kota Bandung yang dilakukan pada tahun 2017, menunjukkan rendahnya tingkat literasi keuangan pelaku UMKM di Kota Bandung. (Nainggolan, 2017). Pemberian kredit usaha pada pelaku usaha yang 
kurang kompeten dapat meningkatkan risiko gagal bayar atas kredit usaha yang diberikan. Tingginya angka kredit bermasalah dapat berdampak negatif pada kondisi perekonomian masyarakat. Oleh karena itu, kegiatan ini penting dilakukan dalam upaya peningkatan literasi keuangan para pelaku UMKM di Kota Bandung.

Permasalahan yang dihadapi oleh UMKM bisa berasal dari faktor internal maupun eksternal. Pertama, Terbatasnya permodalan, Kedua masalah kurangnya pengetahuan dan keterampilan dari sumber daya manusia yang dimiliki Ketiga, terbatasnya jaringan usaha jaringan sehingga mempersulit dalam usaha penetrasi pasar. (Abidin, A.Z., Dharma, 2017). UMKM memiliki peran penting dalam pertumbuhan ekonomi di Indonesia. Peran tersebut diantaranya adalah mampu menyerap tenaga kerja, mengatasi masalah kemiskinan dan membantu pendistribusian hasil-hasil pembangunan. (Hamzah, Lies Maria., Agustien, 2019). Usaha Mikro Kecil dan Menengah (UMKM) menghadapi kendala dalam penyusunan pelaporan keuangan yang sesuai standar, tidak mengetahui berapa keuntungan murni yang didapatkan, kurang pahamnya pengetahuan dasar pencatatan keuangan, kurang pahamnya pengetahuan aplikasi keuangan berbasis android, dan kesulitan mendapatkan pembiayaan dari lembaga keuangan.(Wiratama, Bayu., Kriswanto., Rahayu, Sri., Nugraha, Ambar Rais., Satriawan, 2019)

Dari hulu ke hilir, saluran distribusi yang efektif dibangun dengan trust dan komitmen agar target perusahaan dapat tercapai. (Suwatno., Koeswandi, 2019). Dalam memasarkan produk, terkadang penjual tidak langsung berhubungan dengan kosuumen akhir namun melalui beberapa rantai saluran pemasaran. Saluran saluran tersebut disebut juga dengan multichannel marketing dimana pelaku UMKM berada di tengah tengah jaringan nilai, sebuah sistem kerjasama yang dibuat untuk mendapatkan, menambahkan dan menyampaikan nilai dari produk yang ditawarkan. (Kotler, P., \& Keller, 2016)

Persatuan Pedagang Buku, Jasa Pengetikan dan Grafir Indonesia (Pepebutindo) merupakan salah satu kelompok UMKM yang pada awalnya berdiri pada tahun 1970 untuk memenuhi Komunitas Pedagang Kios Buku, Jasa Pengetikan dan Grafir yang jumlahnya pada saat itu mencapai 100 pemilik kios. Lokasi berjualan anggota Pepebutindo berada di lingkungan sekitar jalan Cikapundung termasuk jalan $A B C$ dan di belakang Factory. Sebagai sentra buku Murah sejak era 1980 hingga awal 2000-an, kawasan Jalan Cikapundung Barat dan sekitarnya memang menjadi salah satu kawasan primadona bagi pecinta buku sebagaimana dapat dilihat pada Gambar 1.
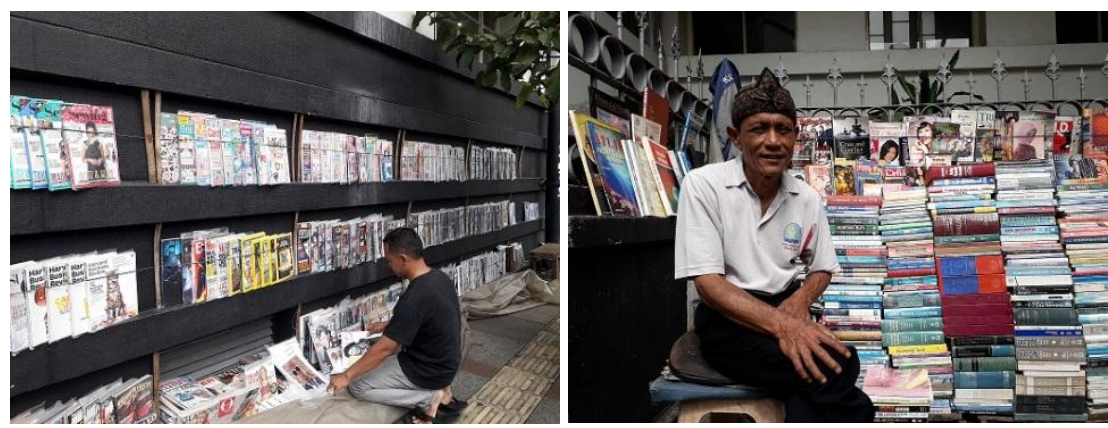

Gambar 1. Suasana Pedagang Buku Di Cikapundung 
Kawasan Cikapundung di dekat Alun-alun Bandung adalah salah satu titik yang paling ramai dikunjungi wisatawan yang hendak melancong ke Kota Bandung, terutama di akhir pekan atau saat liburan. Pedagangnya berjajar hingga ke area yang sekarang menjadi Masjid gaya Klenteng, Al-Imtizaj. Salah satu hal yang dikenal dari kawasan tersebut adalah harga buku yang dijual lebih murah dari harga buku baru di toko. Belakangan ini, kawasan yang dinamai Plaza Cikapundung River Spot tersebut juga kerap digunakan sebagai tempat gelaran aneka bazaar. Belum lagi tren wisata swafoto dengan orang-orang beraneka kostum di sepanjang area Alunalun, menjadikan kawasan ini kerap riuh dengan lalu-lalang pengunjung.

Tak jauh dari keramaian tersebut ada pojok yang cukup sering dilalui pejalan kaki tanpa ditengok, tepatnya di sisi trotoar Jalan Cikapundung Barat. Pojok tersebut di isi tumpukan dan deretan buku yang diatur agar kokoh. Sekilas dilihat, buku-buku yang disediakan cukup beragam, mulai dari majalah gaya hidup hingga buku religi. Dari yang berbahasa Inggris hingga daerah. Kesan yang didapat dari tumpukan buku tersebut adalah bahwa sang penjual telah berdagang dalam waktu yang cukup lama. Pasalnya, sejumlah buku tua, sebagian dengan kertas yang telah menguning, nampak terselip di bawah tumpukan buku anyar. Para pedagang buku telah berjualan aneka buku dan majalah sejak era 1980-an. Jalan Cikapundung Barat ketika itu dipenuhi pedagang aneka buku dan majalah dari ujung jalan ke ujung jalan lainnya. Saat ini hanya tinggal kurang dari 10 pedagang saja.Para penjual buku saat itu harus berbagi lapak yang terbatas karena banyaknya orang. Pembeli pun masih ramai, berbagai kalangan datang mencari bacaan favoritnya.

Pada Tahun 1980 pada saat peringatan Konferensi Asia Afrika, lingkungan sekitar Asia Afrika harus steril dari pedagang Kaki lima, sehingga Komunitas Pepebutindo dipindah ke pinggir Jalan Palasari lalu selanjutnya masuk ke dalam Pasar Inpres Palasari Lantai 2. Pada tanggal 3 Januari 1993 terjadi kebakaran sehingga para pedagang anggota Pepebutindo berpindah ke lokasi Palasari seperti sebagaimana Gambar 2 berikut. Jumlah Anggota Pepebutindo saat ini berjumlah sekitar 200 orang pemilik kios buku, Jasa pengetikan 4 orang dan jasa Grafir 7 orang.

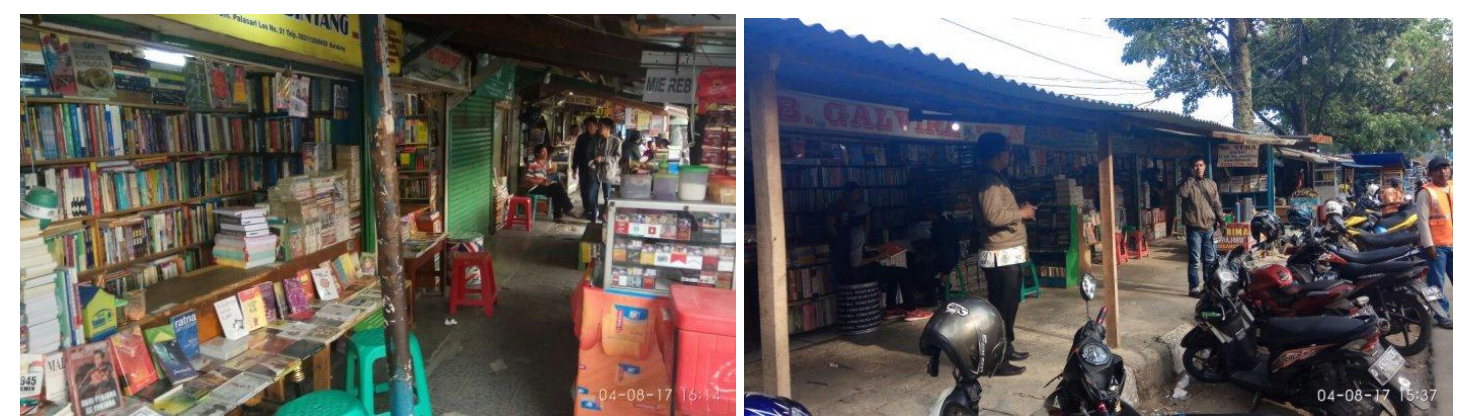

Gambar 2. Suasana Pedagang Buku Di Palasari

Buku merupakan jendela ilmu, dengan membaca buku kita mendapatkan banyak pengetahuan. Dari membaca buku kita akan tahu ilmunya dan akan mudah untuk dibagikan ilmu tersebut. Banyak orang yang berilmu menuliskan pengetahuannya di dalam buku. Saat ini begitu banyak tokok buku yang berada di Bandung seperti Gramedia. Tetapi, ada salah satu pasar yang menjual bermacam-macam buku 
dengan harga yang murah yaitu Pasar Buku Palasari yang terletak di sepanjang Jalan Palasari, Bandung. Pasar Palasari ini cukup terkenal bagi Anda pecinta buku di Kota Bandung, di tempat ini ada berbagai macam buku tersedia seperti novel, buku pelajaran, komik, kamus, dan masih banyak jenis-jenis buku mulai dari tingkat SD hingga universitas berada di pasar ini. (AyoBandung, 2020)

Peluang Peputindo dalam menjual buku dapat dilakukan baik secara eceran maupun secara grosir, bahkan sebagian sudah memanfaatkan media E-Commerce seperti palasarionline.com. Sebagai bursa buku terbesar dan termurah di Indonesia, Bursabuku Palasari memiliki jaringan luas secara nasional dari Aceh sampai Papua bahkan sampai ke Asia Tenggara seperti Singapura, Malaysia, Thailand, dan Filipina. Persoalan SDM yang dihadapi saat ini yaitu terkait dengan pembukuan dan administrasi pencatatan penjualan yang kebanyakan masih dilakukan secara manual sehingga berdampak kepada sulitnya akses ke Lembaga Jasa Keuangan. Selain itu, sebagian besar anggota belum memiliki digital mindset sehingga pemahasan akan Literasi Keuangan dan Teknologi yang sangat rendah untuk para anggota Pepebutindo. Pengetahuan akan literasi keuangan akan mendukung proses pemasaran dan penjualan melalui analisis data historikal.

Sejauh ini tren penjualan buku di Palasari perlahan mulai menurun. Banyak faktor yang menyebabkan hal tersebut, diantaranya penerbit yang langsung menjual buku ke tangan konsumen dan faktor yang paling besar yaitu terkait adanya Pandemi Covid-19 yang menyebabkan pada tahun ajaran baru hampir seluruh siswanya belajar dari rumah sehingga tidak bisa diprediksi potensi ramainya. Para pedagang buku lainnya mengatakan, bahwa pihaknya sempat kucing-kucingan dengan aparat untuk membuka toko. (Detik, 2020)

Masalah sumber daya manusia yang dihadapi oleh Pepebutindo ialah keterampilan dan kompetensi Sumber Daya Manusia dan kecakapan mereka dalam mengelola keuangan usaha. Menejemen produk bagi kalangan usaha sangat diperlukan untuk menata produk kita menjadi lebih teratur sehingga proses bisnis semakin efektif. Rata-rata proses bisnis para pedagang di bawah naungan Pepebutindo dalam memanajemen produk masih bersifat manual seperti contoh saat melakukan pencarian buku. Proses pencarian tersebut hanya dilakukan dengan ingatan saja. Contoh lain yaitu pengkategorian buku sesuai dengan tema atau kategori buku yang masih bercampur dan tidak teratur.

Untuk menangani berbagai masalah tersebut, maka disusun sebuah kerangka kerja yang sudah dilakukan dan rencana yang akan dilakukan. Universitas Langlangbuana selaku Perguruan Tinggi dan lembaga pendidikan yang telah menjadi ikon Kota Bandung, tentunya harus memberikan dampak positif bagi masyarakat di sekitarnya. Solusi yang ditawarkan adalah dengan memberikan pelatihan dan pemahaman literasi keuangan serta pemanfaatan teknologi informasi kepada pelaku UMKM yang akan dikhususkan pada Pepebutindo dalam mendukung program pemerintah untuk menyejahterakan masyarakat di Kota Bandung dalam upaya peningkatan literasi keuangan.

Kerangka kerja dimaksud disusun ke dalam Pengabdian kepada Masyarakat, yaitu kegiatan sivitas akademika yang memanfaatkan Ilmu Pengetahuan dan Teknologi untuk 
memajukan kesejahteraan masyarakat dan mencerdaskan kehidupan bangsa. (Wibawa, 2017). Berdasarkan permasalahan tersebut, tujuan hasil pengabdian yang akan dilakukan, antara lain: Membuat Petunjuk Teknis Digitalisasi Literasi Keuangan dan Melakukan workshop Digitalisasi Literasi Keuangan.

\section{B. METODE}

Metode merupakan tahapan atau langkah-langkah pelaksanaan dalam memberikan solusi yang ditawarkan untuk mengatasi permasalahan mitra. Metode pengabdian yang dilakukan harus mendeskripsikan bahan-bahan yang digunakan dalam kegiatan pengabdian dapat dilihat pada Tabel 1 berikut.

Tabel 1. Metode dan Langkah-Langkah Pelaksanaan

\begin{tabular}{|c|c|c|c|c|}
\hline No & Permasalahan & Solusi & Keluaran & Langkah-Langkah \\
\hline 1 & $\begin{array}{l}\text { Belum tertanamnya digital } \\
\text { mindset pada pelaku usaha } \\
\text { yang menyebabkan tata } \\
\text { kelola yang kurang baik } \\
\text { dari sisi administrasi } \\
\text { pencatatan/pembukuan. }\end{array}$ & $\begin{array}{l}\text { Digitalisasi } \\
\text { Literasi } \\
\text { Keuangan }\end{array}$ & $\begin{array}{l}\text { Petunjuk } \\
\text { Teknis }\end{array}$ & $\begin{array}{l}\text { 1. Pengumpulan Data Literasi } \\
\text { Keuangan dari berbagai } \\
\text { sumber melalui observasi, } \\
\text { interview dan FGD } \\
\text { 2. Membuat Analisa dan } \\
\text { perancangan berdasarkan } \\
\text { hasil pemetaan kebutuhan } \\
\text { Mitra berdasarkan hasil } \\
\text { FGD } \\
\text { 3. Pembuatan Petuniuk Teknis } \\
\text { Digitalisasi } \\
\text { Keuangan }\end{array}$ \\
\hline 2 & $\begin{array}{l}\text { Rendahnya pengetahuan } \\
\text { tentang literasi dan inklusi } \\
\text { keuangan sebagai salah } \\
\text { satu solusi } \\
\text { meningkatkan dalam } \\
\text { usahanya. }\end{array}$ & $\begin{array}{l}\text { Workshop } \\
\text { Literasi } \\
\text { Keuangan }\end{array}$ & Workshop & $\begin{array}{l}\text { 1. Pembuatan Materi } \\
\text { Presentasi } \\
\text { 2. Pendataan peserta } \\
\text { anggota Pepebutindo } \\
\text { 3. Penyediaan Sarana } \\
\text { Prasarana } \\
\text { 4. Pelaksanaan Workshop }\end{array}$ \\
\hline
\end{tabular}

Kegiatan Pengabdian Kepada Masyarakat melibatkan 2 (dua) orang dosen dan 2 (dua) orang mahasiswa dalam pelaksanaannya yang berlangsung selama 6 (enam) bulan. Peta lokasi mitra dilengkapi dengan jarak mitra dengan Perguruan Tinggi dapat dilihat pada Gambar 3 berikut:

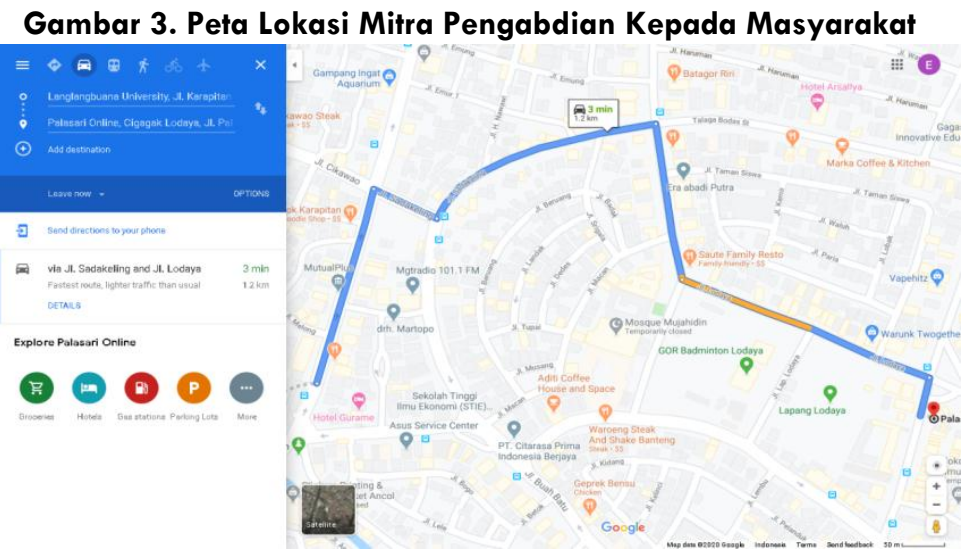


Adapun jadwal pelaksanaan Pengabdian Kepada Masyarakat, dapat dilihat pada Tabel 2 berikut:

Tabel 2. Jadwal Pelaksanaan Pengabdian Kepada Masyarakat

\begin{tabular}{|c|l|c|c|c|c|c|c|}
\hline \multirow{2}{*}{ NO. Jenis Kegiatan } & \multicolumn{1}{|c|}{ Bulan ke- Tahun 2020} \\
\cline { 4 - 7 } & & $\mathbf{7}$ & $\mathbf{8}$ & $\mathbf{9}$ & $\mathbf{1 0}$ & $\mathbf{1 1}$ & $\mathbf{1 2}$ \\
\hline 1. & Persiapan Kegiatan PkM & & & & & & \\
\hline 2. & Kunjungan ke Pepebutindo & & & & & & \\
\hline 3. & $\begin{array}{l}\text { Pembuatan Petunjuk Teknis Digitalisasi } \\
\text { Literasi Keuangan }\end{array}$ & & & & & & \\
\hline 4. & $\begin{array}{l}\text { Pelaksanaan Kegiatan Pelatihan Literasi } \\
\text { Keuangan }\end{array}$ & & & & & & \\
\hline 5. & Pembuatan Laporan Kegiatan PkM & & & & & & \\
\hline
\end{tabular}

\section{HASIL ATAU PEMBAHASAN}

Hasil dari kegiatan pengabdian kepada masyarakat ini ialah peningkatan pengetahuan dan pemahaman literasi kevangan dengan memanfaatkan teknologi informasi para mitra/peserta pelatihan (dalam hal ini pelaku usaha Pepebutindo). Pepebutindo dipimpin oleh seorang Ketua, dibantu oleh Wakil Ketua, Sekretaris, dan Bendahara. Secara umum, struktur organisasi Pepebutindo dapat dilihat sebagaimana Gambar 4 berikut:

\section{Pepebutindo}

Persatuan Pedagang Buku, Jasa Pengetikan dan Grafir Indonesia

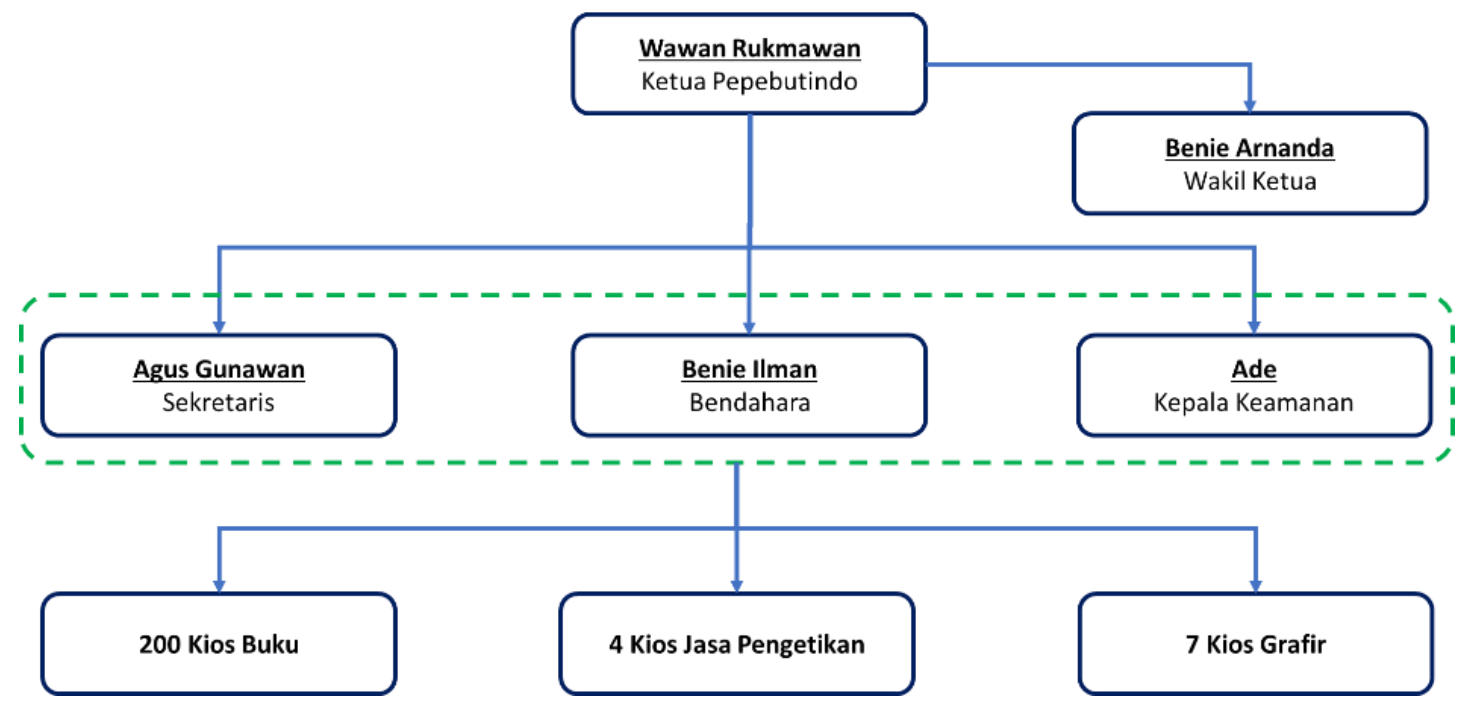

Gambar 4. Struktur Organisasi Pepebutindo

Tingkat pemahaman pelaku Usaha Mikro Kecil dan Menengah (UMKM) terhadap sistem manajemen administrasi masih sangat rendah. Berdasarkan survei Otoritas Jasa Keuangan (OJK), tingkat pemahaman dan kemampuan UMKM dalam menyusun sistem administasi keuangan hanya sekitar 20\%. Oleh karena itu, Bank Indonesia (BI) berusaha mendorong kemajuan usaha pelaku UMKM dengan menciptakan Sistem Aplikasi Pencatatan Informasi Keuangan (SiAPIK), yaitu sebuah sistem yang berguna mencatat transaksi keuangan dan laporan keuangan masing-masing pelaku. (Linangkung, 2017) 
Setelah mengikuti pelatihan, peserta diharapkan mampu mengelola kevangan usaha mereka dengan lebih baik dan menyadari pentingnya melakukan pembukuan atau pencatatan keuangan usaha, sehingga mereka dapat mengakses sumber modal dengan baik. Dalam tataran lebih luas, kegiatan ini diharapkan dapat mendukung program pemerintah dalam upaya peningkatan literasi keuangan masyarakat Kota Bandung.

Gambaran Iptek yang akan diimplentasikan di Mitra sasaran yaitu Digitalisasi Literasi Keuangan. Dalam pelaksanaan PkM ini terdapat produk Iptek yang bisa diterapkan kepada mitra khususnya terkait dengan manajemen keuangan, yaitu aplikasi SI APIK. Aplikasi tersebut mampu membantu masyarakat dalam mencatat keuangan, membuat anggaran, merencanakan keuangan, mengelola, investasi, dan membuat laporan keuangan. Berikut Gambar 5 merupakan tampilan dari aplikasi SI APIK.

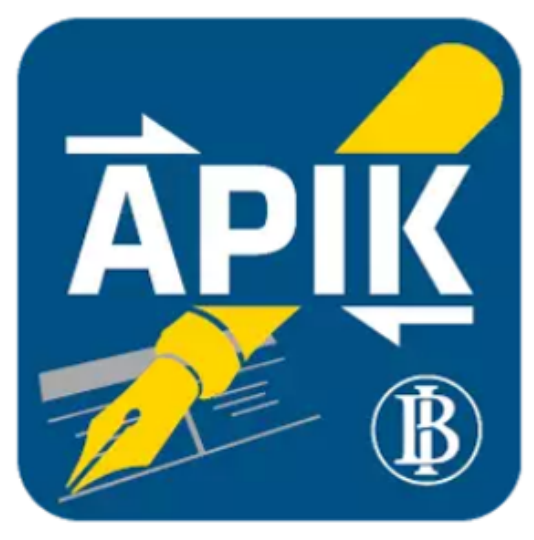

\section{SI APIK}

Bank Indonesia

$3+$

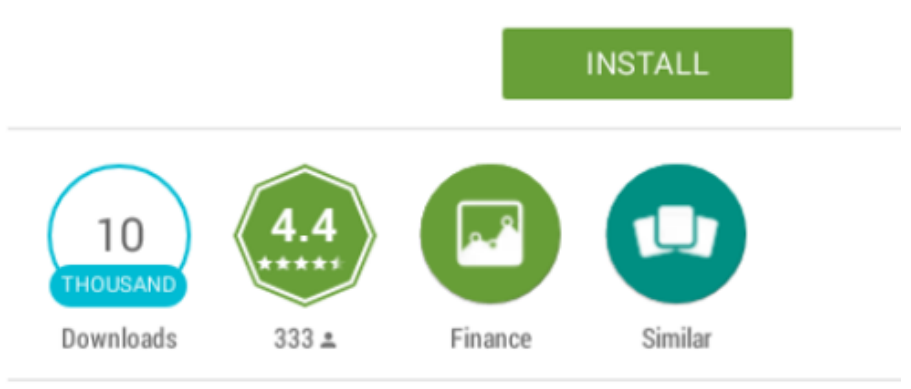

Application of Financial Information Record (SI APIK)

Gambar 5. Aplikasi SI APIK

Salah satu cara mencapai kesejahteraan kevangan adalah dengan meningkatkan literasi kevangan sehingga para pelaku usaha bisa mengelola keuangan mereka sendiri dan berdampak pada kinerja usaha yang lebih produktif. Berikut beberapa modul yang dimiliki oleh aplikasi SI APIK :

1. Pilihan Jenis Usaha

Berikut Gambar 6, merupakan menu pemilihan jenis usaha pada aplikasi SI APIK 
Pilih sektor usaha Anda

\begin{tabular}{ll}
\hline Jasa & X \\
\hline Perdagangan & \\
\hline Manufaktur & \\
\hline Pertanian & $\times$ \\
\hline
\end{tabular}

\section{Selanjutnya}

Gambar 6. Menu Pemilihan Jenis Usaha Pada Aplikasi SI APIK

2. Dashboard

Berikut Gambar 7, merupakan dashboard kumpulan menu pada aplikasi SI APIK yang terdiri dari Menu Transaksi (Penerimaan, Pengeluaran, Penjualan, Utang, Penghasilan Lain, Penarikan Dari Bank), Master Data, Laporan, Info Aplikasi, Info Pengguna, Aktifkan Petunjuk, Backup Database, Restore Database, Ganti User dan Tambah User.

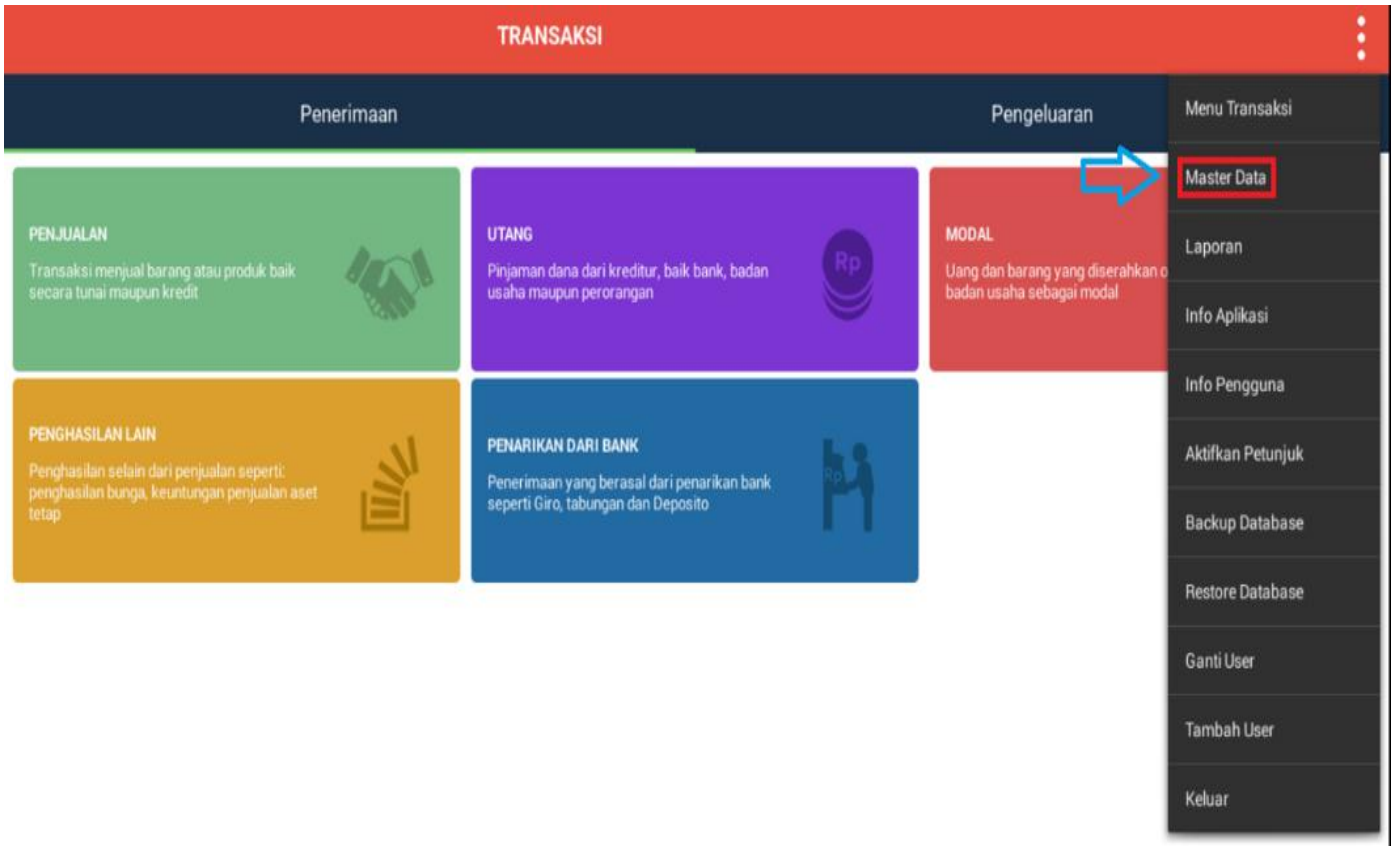

Gambar 7. Menu Dashboard Pada Aplikasi SI APIK 
3. Master Data

Berikut Gambar 8, merupakan menu Master Data pada aplikasi SI APIK yang terdiri dari Menu Kategori Barang, Master Aset, Master Biaya Lain, Master Bank, Master Bank Pemberi Pinjaman, Master Satuan Barang, Master Mata Uang, Master Kas Valas, Master Aset Lain dan Master Saldo Awal.

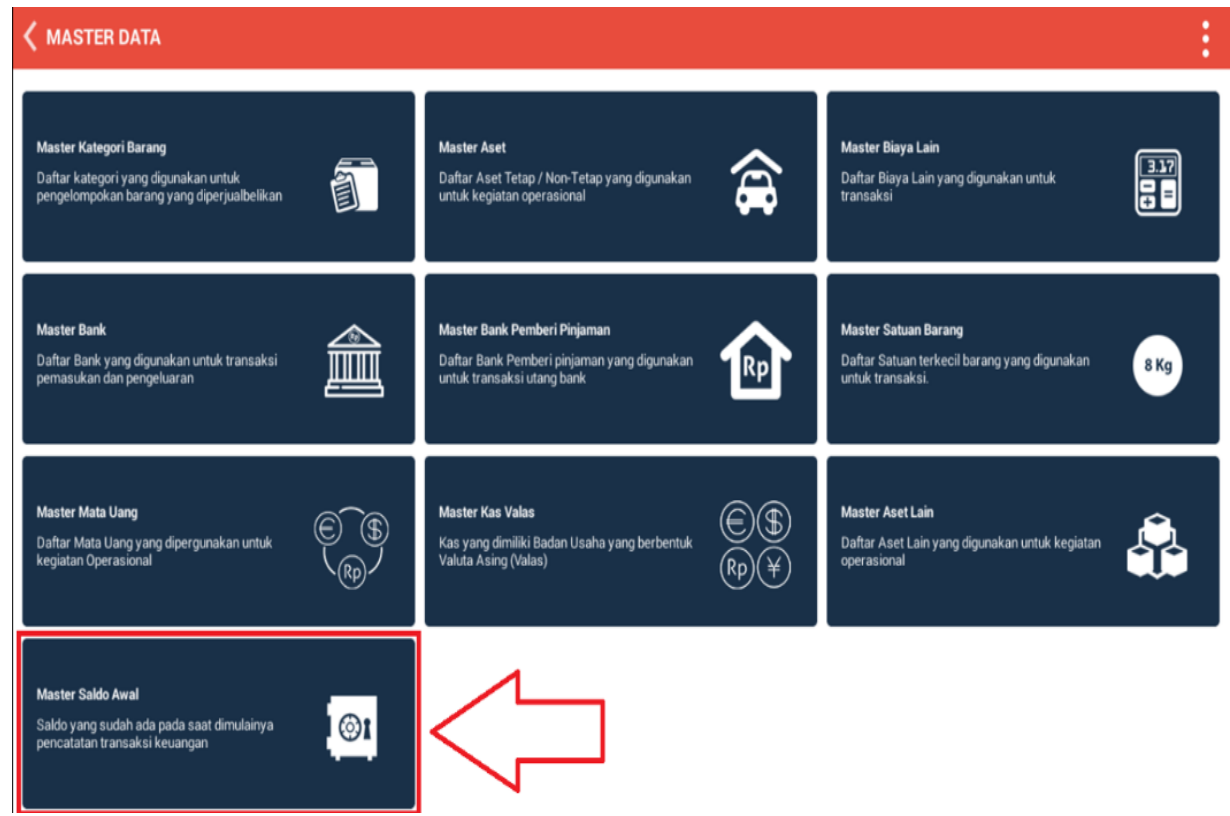

Gambar 8. Menu Master Data Pada Aplikasi SI APIK

4. Master Saldo Awal

Berikut Gambar 9, merupakan menu Master Saldo Awal pada aplikasi SI APIK yang terdiri dari Menu Kas, Giro, Tabungan, Deposito, Piutang Usaha, Persediaan, Beban Dibayar Di Muka, Aset Tetap, Aset Lain dan Utang Usaha.

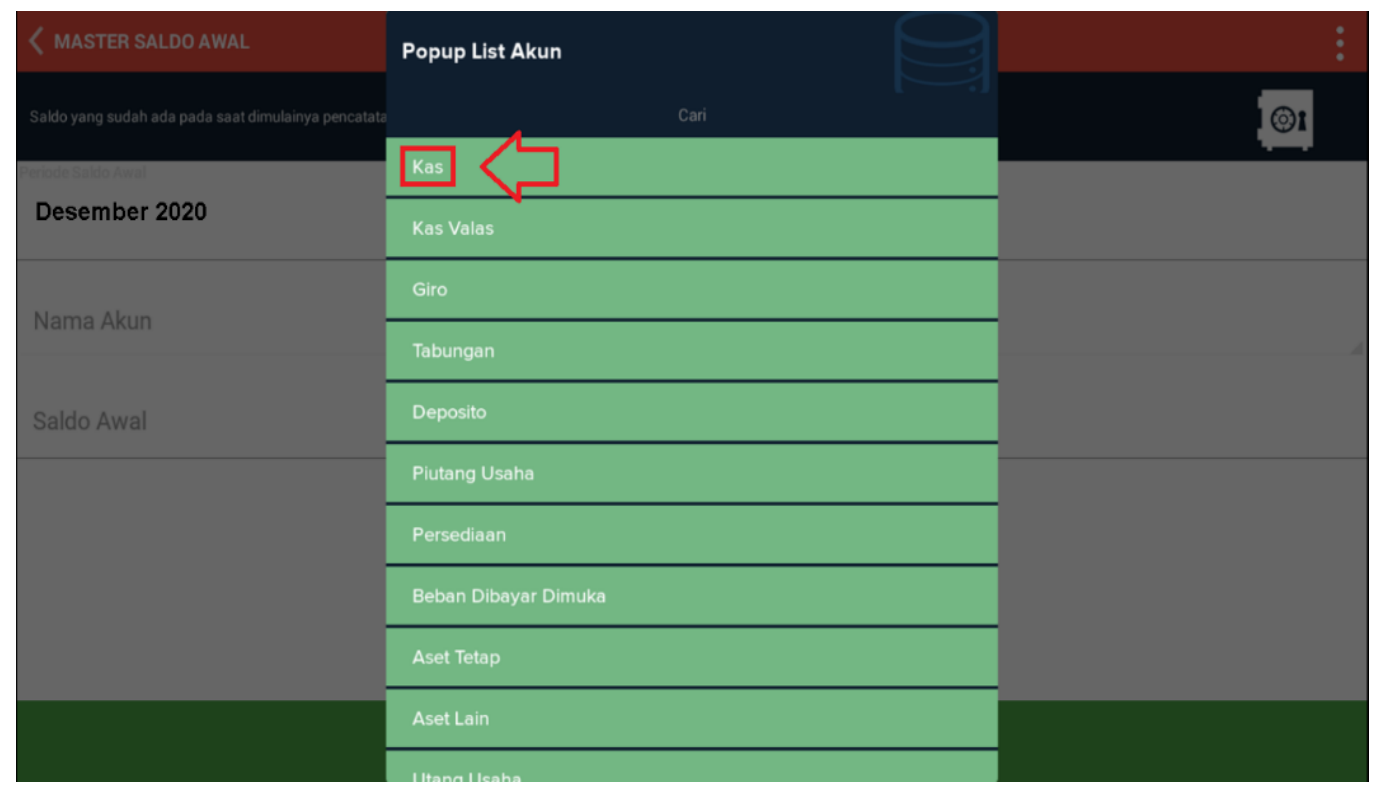

Gambar 9. Menu Saldo Awal Pada Aplikasi SI APIK 
Kelebihan aplikasi SI APIK antara lain mampu mencatat proses akuntansi hingga penyusunan laporan keuangan. Pencatatan Transaksi keuangan untuk Sektor Perdagangan yang bergerak dalam penyediaan dan distribusi barang yang dibutuhkan masyarakat melalui mekanisme pasar baik perdagangan domestik maupun internasional. Siklus Akuntansi usaha kecil badan usaha bukan badan hukum dapat dilihat pada Gambar 10 berikut:
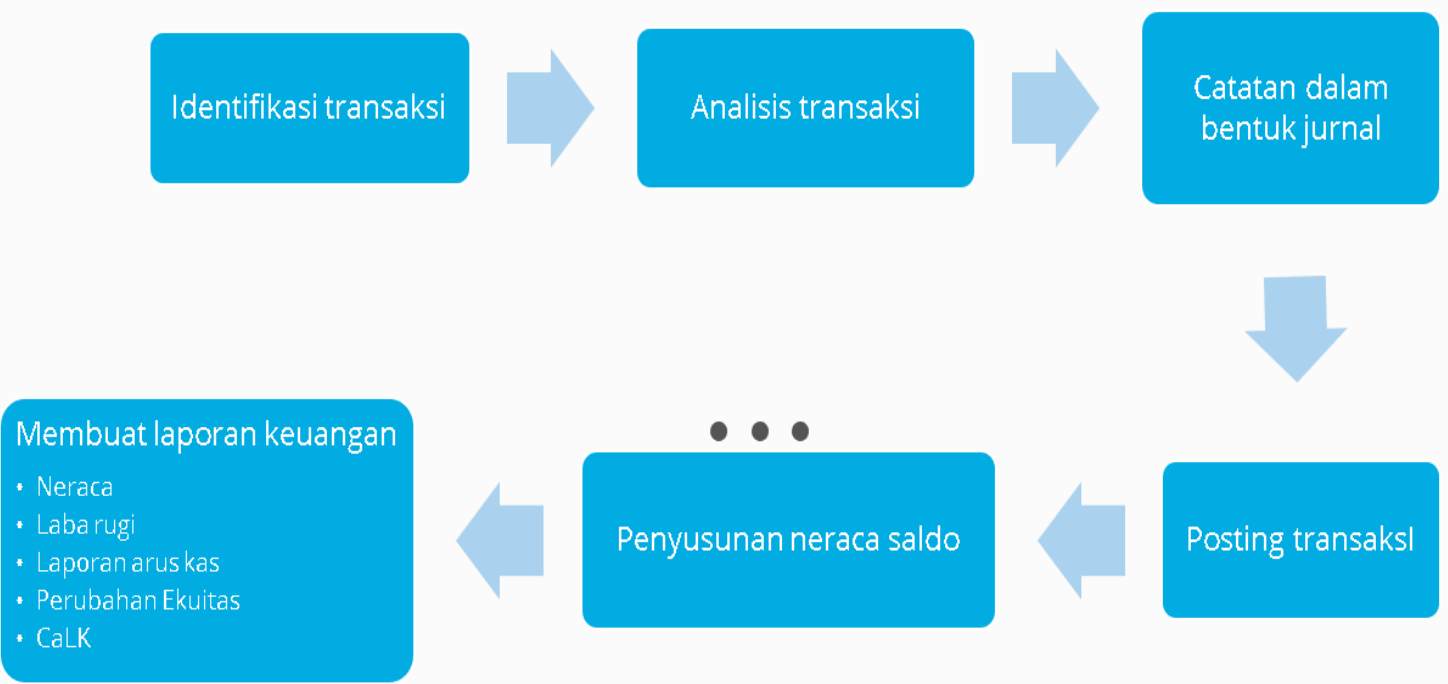

Gambar 10. Siklus Akuntansi Usaha Kecil Menggunakan Aplikasi SI APIK

Partisipasi mitra terhadap metode \& langkah-langkah pelaksanaan yang dilakukan oleh Tim PKM dapat dilihat pada Tabel 3 berikut:

Tabel 3. Partisipasi Mitra

\begin{tabular}{|c|c|c|c|}
\hline No & Permasalahan & Solusi & Partisipasi Mitra \\
\hline 1 & $\begin{array}{l}\text { Rendahnya pengetahuan tentang } \\
\text { literasi dan inklusi keuangan } \\
\text { sebagai salah satu solusi dalam } \\
\text { meningkatkan potensi usahanya. }\end{array}$ & $\begin{array}{l}\text { Petunjuk } \\
\text { Teknis }\end{array}$ & $\begin{array}{l}\text { 1. Pendampingan Observasi; } \\
\text { 2. Wawancara dengan Tim PKM; } \\
\text { 3. Penyediaan Ruang Pertemuan; } \\
\text { 4. Pembahasan Agenda Pelatihan; } \\
\text { 5. Pendataan dan Assessment } \\
\text { peserta anggota Pepebutindo; } \\
\text { 6. Penyediaan Sarana Prasarana. }\end{array}$ \\
\hline 2 & $\begin{array}{l}\text { Belum tertanamnya digital mindset } \\
\text { pada pelaku usaha yang } \\
\text { menyebabkan tata kelola yang } \\
\text { kurang baik dari sisi administrasi } \\
\text { pencatatan/pembukuan. }\end{array}$ & Workshop & $\begin{array}{l}\text { 1. Serah Terima Petunjuk Teknis } \\
\text { Digitalisasi Literasi Keuangan SI } \\
\text { APIK; } \\
\text { 2. Monitoring \& Evaluasi penerapan } \\
\text { digital mindset pada seluruh } \\
\text { anggota Pepebutindo. }\end{array}$ \\
\hline
\end{tabular}


Secara singkat, hasil pengabdian kepada masyarakat yang dilakukan dapat dilihat pada Tabel 4 berikut :

Tabel 4. Hasil/Kemajuan Yang Diperoleh Mitra

\begin{tabular}{|c|c|c|c|}
\hline No & Permasalahan & Solusi & $\begin{array}{c}\text { Hasil/Kemajuan Yang Diperoleh } \\
\text { Mitra }\end{array}$ \\
\hline 1 & $\begin{array}{l}\text { Rendahnya pengetahuan tentang } \\
\text { literasi dan inklusi keuangan } \\
\text { sebagai salah satu solusi dalam } \\
\text { meningkatkan potensi usahanya. }\end{array}$ & $\begin{array}{l}\text { Pelatihan } \\
\text { Literasi } \\
\text { Keuangan }\end{array}$ & $\begin{array}{l}\text { a. Bertambahnya pengetahuan } \\
\text { tentang literasi dan inklusi } \\
\text { keuangan sebagai salah satu } \\
\text { solusi dalam meningkatkan } \\
\text { potensi usahanya. }\end{array}$ \\
\hline 2 & $\begin{array}{l}\text { Belum tertanamnya digital } \\
\text { mindset pada pelaku usaha yang } \\
\text { menyebabkan tata elola yang } \\
\text { kurang baik dari sisi administrasi } \\
\text { pencatatan / pembukuan. }\end{array}$ & $\begin{array}{l}\text { Digitalisasi } \\
\text { Literasi } \\
\text { Kevangan }\end{array}$ & $\begin{array}{l}\text { a. Tertanamnya budaya digital } \\
\text { mindset. } \\
\text { b. Tata kelola yang lebih baik } \\
\text { dari sisi administrasi } \\
\text { pencatatan/ pembukuan. }\end{array}$ \\
\hline
\end{tabular}

Kendala yang dihadapi dalam pelaksanaan kegiatan pengabdian kepada masyarakat di Pepebutindo antara lain :

1. Keterbatasan waktu dari para pedagang untuk mengikuti kegiatan workshop.

2. Pemahaman para pedagang akan pentingnya digital mindset.

3. Kebiasaan pembukuan secara manual selama bertahun-tahun.

Dalam rangka mengatasi permasalahan tersebut, maka tim pengabdian kepada masyarakat melakukan serah terima dokumen Petunjuk Teknis Digitalisasi Literasi Keuangan menggunakan SI APIK sebagaimana Gambar 11 di bawah ini:

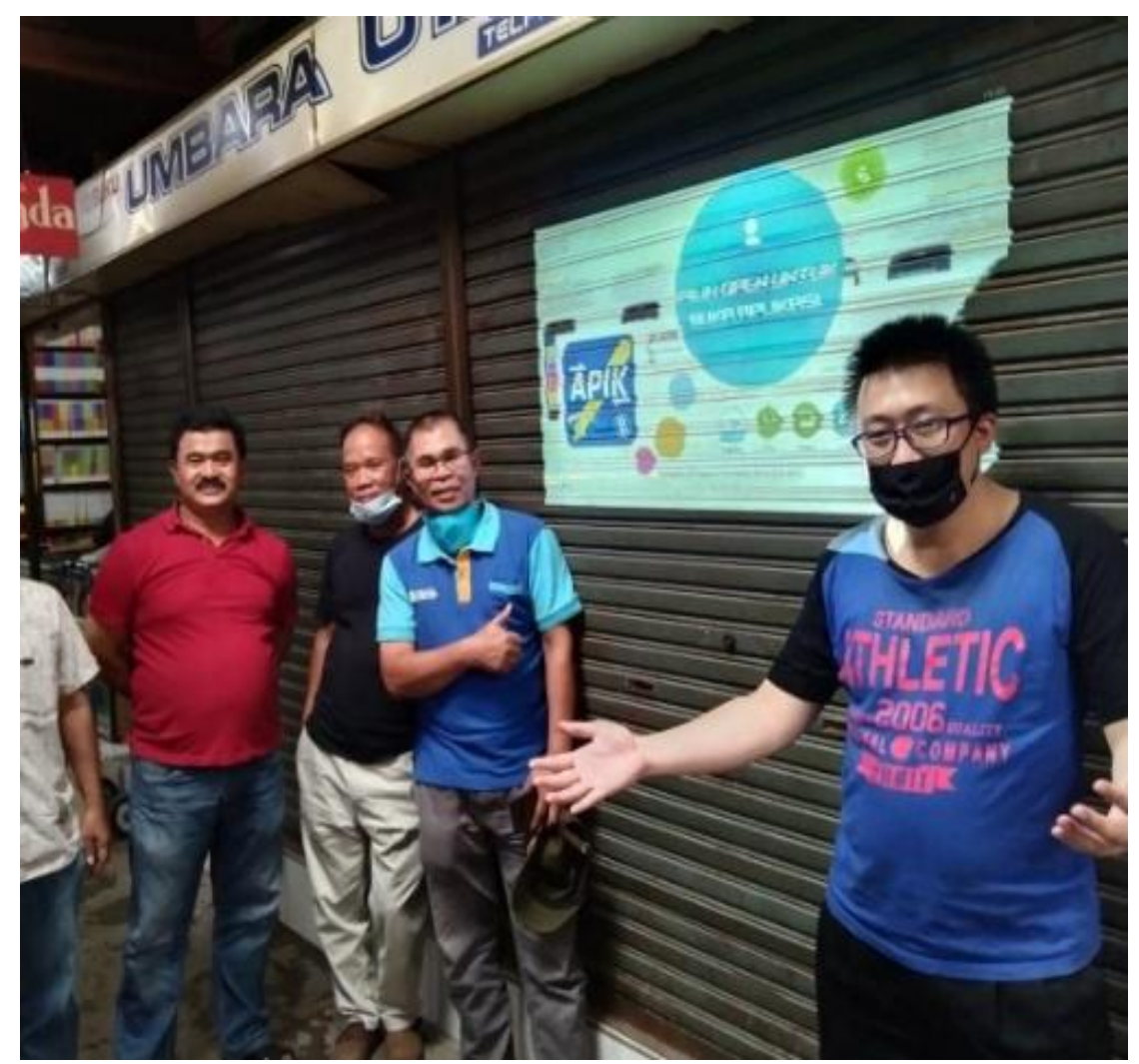



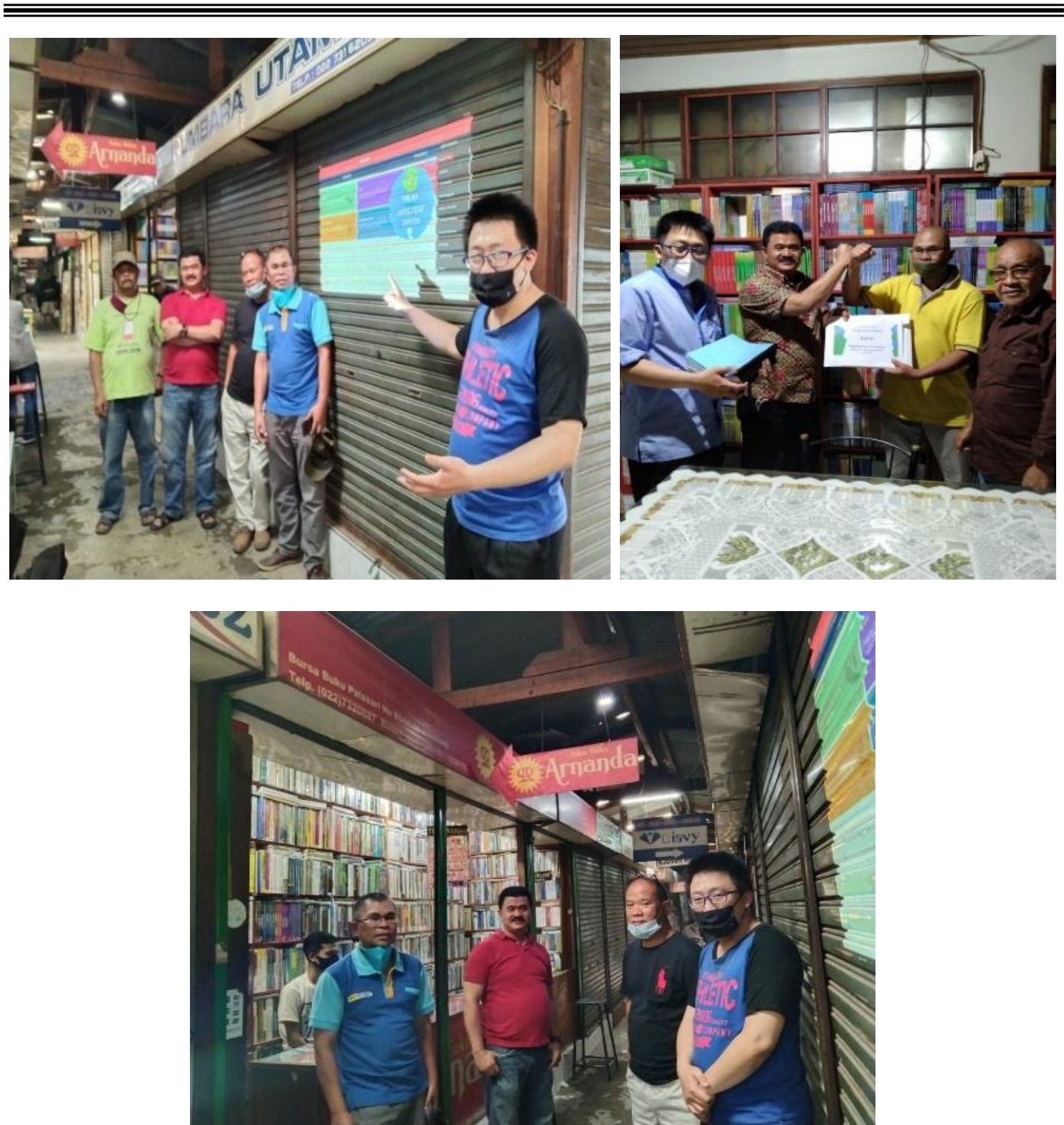

Gambar 11. Serah Terima Dokumen Petunjuk Teknis Digitalisasi Literasi Keuangan

\section{PENUTUP}

Berdasarkan hasil dan pembahasan tersebut, kesimpulan yang diperoleh dari kegiatan pengabdian kepada masyarakat, antara lain :

1. Hasil observasi, interview dan FGD yang telah dilakukan Bersama anggota Pepebutindo telah menjadi dasar dalam penyusunan Petunjuk Teknis Digitalisasi Literasi Keuangan menggunakan Aplikasi SI APIK.

2. Tim pengabdian kepada masyarakat telah melakukan workshop Digitalisasi Literasi Keuangan menggunakan Aplikasi SI APIK, yang diikuti oleh para pedagang Pepebutindo. Selanjutnya pada sesi berikutnya, dilakukan serah terima sebanyak 50 (lima puluh) Petunjuk Teknis Digitalisasi Literasi Keuangan menggunakan Aplikasi SI APIK kepada Ketua Pepebutindo untuk meningkatkan digital mindset para pedagang Pepebutindo. 
Setelah pelaksanaan kegiatan pengabdian kepada masyarakat selesai, maka rekomendasi penelitian/pengabdian selanjutnya yang akan dilakukan, antara lain:

1. Merekomendasikan Pepebutindo sebagai organisasi yang dapat dijadikan mitra usaha/mitra kerja sama untuk meningkatkan kualitas pembelajaran bagi dosen, mahasiswa dan tenaga pendidik di Perguruan Tinggi.

2. Melakukan monitoring terkait implementasi digital mindset pada para pedagang di Palasari yang berada di bawah kelolaan Pepebutindo dalam hal tata kelola pencatatan pembukuan dan administrasi.

3. Melaksanakan pelatihan lanjutan mengenai Inklusi Keuangan dan Financial Technology.

\section{E. UCAPAN TERIMA KASIH.}

Ucapan terima kasih kami sampaikan kepada Universitas Suryakancana, khususnya kepada tim panitia. Terima kasih juga kepada Universitas Langlangbuana Lembaga Pengabdian Kepada Masyarakat atas dukungan dana dan mahasiswa kami dari Fakultas Teknik Program Studi Informatika yang telah membantu dan mendampingi kami dalam melaksanakan kegiatan Pengabdian Kepada Masyarakat di Pepebutindo.

\section{F. DAFTAR PUSTAKA.}

Abidin, A.Z., Dharma, M. B. (2017). Strategi Pengembangan Usaha Mikro Kecil dan Menengah Dinas Koperasi dan UKM Kota Tangerang Selatan. Prosiding Seminar Ilmiah Nasional.

AyoBandung. (2020). Pasar Buku Palasari - Gudangnya Semua Buku. https://www.ayobandung.com/read/2019/07/03/56673/pasar-buku-palasarigudangnya-semua-buku

Bandung, P. (2016). Bandung Menjawab BPR. https://portal.bandung.go.id

Detik. (2020). Pasar Buku Palasari Bandung Kembali Bergeliat di Era New Normal. https://news.detik.com/berita-jawa-barat/d-5073977/pasar-buku-palasaribandung-kembali-bergeliat-di-era-new-normal

Hamzah, Lies Maria., Agustien, D. (2019). Pengaruh Perkembangan Usaha Mikro, Kecil dan Menengah Terhadap Pendapatan Nasional Pada Sektor UMKM di Indonesia. Jurnal Ekonomi Pembangunan, 8(2), 215-227.

Kotler, P., \& Keller, K. (2016). Marketing Management (Global Edition). Harlow: Pearson Education Limited.

Linangkung, E. (2017). Aplikasi SiApik, Cara Tingkatkan UMKM Melek Administrasi Keuangan.

SindoNews. https://tekno.sindonews.com/berita/1 188308/133/aplikasi-siapik-caratingkatkan-umkm-melek-administrasi-keuangan

Nainggolan, D. (2017). Pengukuran dan Pelatihan Literasi Keuangan Usaha Mikro, Kecil, dan Menengah (UMKM) Kota Bandung. 
Sudaryanto, H. A. (2002). Evaluasi Kesiapan UKM Menyongsong Pasar Bebas Asean (AFTA): Analisis Perspektif dan tinjauan Teoritis. Jurnal Ekonomi Akuntansi Dan Manajemen, $1(2)$.

Sunardi, Nardi; Lesmana, Rosa; Kartono; Rudy; Hasbiyah, W. (2020). Peran Manajemen Keuangan dan Digital Marketing dalam Upaya Peningkatan Omset Penjualan bagi Umkm Pasar Modern Intermoda BSD City Kota Tangerang Selatan di Tengah Pandemi Covid-19. Jurnal Abdi Masyarakat, 2(1), 20-27.

Suwatno., Koeswandi, T. (2019). Contextual Marketing Communication. Cendikia.

UKM, K. K. dan. (2017). Data Usaha Mikro, Kecil, Menengah (UMKM) dan Usaha Besar (UB). http://www.depkop.go.id/berita-informasi/data-informasi/data-umkm/

Wibawa, S. (2017). Tridharma Perguruan Tinggi (Pendidikan Dan Pengabdian Kepada Masyarakat). https://unindra.ac.id/assets/uploads/file-80.pdf

Wiratama, Bayu., Kriswanto., Rahayu, Sri., Nugraha, Ambar Rais., Satriawan, Y. (2019). Penerapan Aplikasi Keuangan Berbasis Android "Si Apik" pada Penyusunan Laporan Keuangan UMKM Biofarmakaka Desa Limbangan Kendal. Jurnal Rekayasa, $17(1), 16-24$. 